\title{
Collaborative Education Countermeasures for Innovation and Entrepreneurship Education in Higher Vocational Colleges Based on the Background of "Curriculum Ideological and Political Education"
}

\author{
Xin Zhou \\ Human Resources Department, Chongqing College of Electronic Engineering, Chongqing, China
}

\begin{abstract}
The concept of "curriculum ideological and political education" expands new ideas for innovation and entrepreneurship education in colleges and universities, and plays an effective role in solving many problems existing in entrepreneurship education. Based on the background of "curriculum ideological and political education", this paper explores the countermeasures of collaborative education in innovation and entrepreneurship education in higher vocational colleges, and constructs the ecological collaborative education path of "5 platforms + 2 chains" and "four in one", which is helpful to enhance the long-term effect of dual-innovation education in higher vocational colleges, and then form the joint force of education.
\end{abstract}

Keywords: Curriculum ideological and political education, Technical secondary school, Innovation and entrepreneurship education, Collaborative education countermeasures.

\section{Introduction}

With the continuous development and adjustment of social and economic structure, the demand for innovative and entrepreneurial talents in society is constantly increasing. Schools should pay enough attention to college students' innovative and entrepreneurial thinking, innovative and entrepreneurial quality and innovative and entrepreneurial ability. However, at present, the situation and educational achievements of innovation and entrepreneurship education in higher vocational colleges are not optimistic, and the cultivation of such talents is difficult to meet the needs of current social and economic construction and development. From the comparison of teaching forms in higher vocational colleges, innovation and entrepreneurship education is rarely integrated with professional discipline education and teaching links. Paying too much attention to the teaching of theoretical knowledge is not conducive to improving students' comprehensive practical ability. If "ideological and political education" is integrated into mass entrepreneurship and innovation education, let "ideological and political education" guide students to establish a correct outlook on life, wealth and values, cultivate their will to face difficulties and noble moral sentiments, enhance their sense of social responsibility, and then enhance their ability and competitiveness to adapt to society; Let innovation and entrepreneurship education more in line with the requirements of contemporary college students' development law of the times and form a good connection with it, which can better reflect the practicality and times of innovation and entrepreneurship education and truly clarify the development direction of life. Therefore, "ideological and political education" and "innovation and entrepreneurship education" cooperate with each other and bring out the best in each other, which promotes the organic connection among education chain, talent chain and innovation chain. It has positive practical significance for optimizing the talent training mode, effectively improving the quality of innovative talents training and effectively solving the current employment difficulties of college students.

\section{The Significance of the Collaborative Education of Ideological and Political Education and Innovation and Entrepreneurship Education}

2.1 Conducive to the Implementation of the National Innovation-driven Development Strategy

The realistic new economic form puts forward new requirements for cultivating innovative technical and technical talents. The Guiding Outline of Curriculum Ideological and Political Construction in Colleges and Universities issued in May 2020 comprehensively promotes and implements the fundamental task of cultivating people by virtue and improves the quality of personnel training. In the same year, the national "Several Opinions on Deepening the Reform and Innovation of Ideological and Political Theory Courses in Schools in the New Era" comprehensively promoted the ideological and political construction of college courses and put ideological and political education into the personnel training system. In 2021, the State Council issued the Outline of the Action Plan for Scientific Quality of the Whole People (2021-2035), pointing out that the national innovation and entrepreneurship training plan for college students should be implemented in depth, and college students should be supported to carry out innovative experiments, entrepreneurship training and entrepreneurship practice projects, and various scientific and technological innovation practice activities should be vigorously carried out. On the same day, the Education Committee of Chongqing Municipal Committee of the Communist Party of China issued the Action Plan for Curriculum Ideological and Political 
Construction in Chongqing Colleges and Universities (2021-2025), and the curriculum ideological and political construction was continuously strengthened and promoted. The introduction of these policies contains rich elements of ideological education, which is very necessary for the education mechanism of innovation and entrepreneurship integrating ideological and political education. It conforms to the requirements of high-quality economic development in the new era and is an inevitable choice for implementing the national innovation-driven development strategy.

\subsection{It is Conducive to Realizing the All-round Education of Ideological and Political Education and Professional Education}

The Guiding Outline of Curriculum Ideological and Political Construction in Colleges and Universities emphasizes[2], "Let all colleges and universities, all teachers and all courses bear the responsibility of educating people, keep a good canal, plant a good field of responsibility, make all kinds of courses go with curriculum ideological and political education in the same direction, unify explicit education with implicit education, form a synergistic effect, and build a large pattern of educating all employees in all directions". Among them, the important carrier of curriculum ideological and political construction is professional education, which also injects more vivid vitality into professional education and shows the charm of soul. In today's increasingly developing society, the way of thinking and value orientation of college students have a vital impact on the development of society to a certain extent. At present, many colleges and universities combine the ideological and political education system according to the unique theoretical perspective of professional courses, A large number of entrepreneurial practice bases have been established, Effectively promote and optimize the rapid development of science and technology enterprises, Give birth to more micro-enterprises, make them present professional ideological and political education of innovation and entrepreneurship, realize the education process of teaching professional knowledge and guiding correct values in the process of entrepreneurship simultaneously, create a golden classroom in which curriculum ideological and political education and innovation and entrepreneurship education cooperate from multiple angles, and achieve the goal of all-round education.

2.3 It is Conducive to Realizing the Whole Process of Educating People in Coordination Between Ideological and Political Education and Dual-Innovation Education

With the deepening of social development, the concept of college teachers is gradually developing to a broader space. Gradually change the traditional teaching ideas, integrate the ideological and political ideas of the curriculum into the teaching field of dual-creation majors, and promote the teaching effect of moral education to improve rapidly. Consolidate the elements of "curriculum ideological and political education" in the process of innovation and entrepreneurship education, improve students' innovation and entrepreneurship ability and ideological and political quality in the teaching process, cultivate students' good psychological quality and innovative inquiry spirit, start their own businesses, adapt to the development of the times and realize self-worth. Relying on the "Internet plus" college students' innovation and entrepreneurship competition, the "Challenge Cup" competition to promote teaching activities, the simulation practice activities of curriculum training, the social practice activities in winter and summer vacations, etc., To expand the channels of "curriculum ideological and political education" in the practice activities of mass entrepreneurship and innovation education in higher vocational colleges, Promote the effectiveness of innovation and entrepreneurship education, enhance the adaptability of vocational education, train entrepreneurs to have the courage to pursue dreams, Do not forget your initiative mind's persistence and indomitable integrity in the process of innovation and entrepreneurship, train more high-quality technical and technical talents, craftsmen and skilled craftsmen from big countries, and complete the whole process of educating people.

\section{The Current Situation of Innovation and Entrepreneurship Education in Higher Vocational Colleges under the Background of "Curriculum Ideological and Political Education"}

\subsection{The Teacher Mechanism for Carrying out Mass Entrepreneurship and Innovation Education is not Perfect}

To effectively carry out the dual-innovation education for college students, it is necessary to establish a perfect educational subject mechanism and an efficient and high-level teaching staff. At present, the teachers who carry out "mass entrepreneurship and innovation" education are generally limited, the professional innovation and entrepreneurship education team is limited, the teachers with innovation and entrepreneurship background and innovation and entrepreneurship practice experience are generally lacking, and the exploration and practical skills of innovation and entrepreneurship education teaching mode are lacking, resulting in the lack of sufficient attraction of innovation and entrepreneurship education classroom effectiveness. In addition, the imbalance between teachers and students in school is serious, which can not meet the learning needs of special groups of entrepreneurial college students in an all-round way. There are communication and communication lags behind among educational subjects, and the network chain of entrepreneurship education with multi-participation is dissolved, and the implementation of entrepreneurship education is not in place from time to time. At the same time, there are still imperfect communication mechanisms between universities, parents and society, and there are obvious obstacles to effective communication. Without the support of parents and the cooperation of society, effective solutions can not be found when problems arise.

\subsection{The Ideological Role of Carrying out Mass Entrepreneurship and Innovation Education is Unclear}

With the promulgation and implementation of relevant national policies, colleges and universities have set up targeted entrepreneurship education courses and given some meaningful guidance, but they still exist in the theoretical 
level, which cannot form an effective integration with related majors, and the ideological role is ignored, and the educational effect is not significant. There is a lack of practical experience in innovation and entrepreneurship, and students lack sufficient risk assessment on the hardship, durability and reality of innovation and entrepreneurship. When encountering obstacles, they are prone to psychological emotions such as conflict, contradiction, entanglement and fear. At the same time, the entrepreneurial goal is unclear, the reasonable implementation plan is lacking, and the entrepreneurial path is unclear. This is not conducive to the enhancement of college students' entrepreneurial ability, but also leads to the failure of their entrepreneurship. Therefore, it is necessary to strengthen the reform of innovation and entrepreneurship education, promote the training of comprehensive talents in colleges and universities, further optimize the ways of innovation and entrepreneurship education based on the background of curriculum ideological and political education, and effectively solve the problems existing in innovation and entrepreneurship education in colleges and universities through the organic integration of "curriculum ideological and political education" construction and collaborative education of innovation and entrepreneurship education in higher vocational colleges.

\subsection{The Teaching Resources for Carrying out Mass Entrepreneurship and Innovation Education are not Abundant}

Classroom teaching, social practice, special lectures, science and technology competition, etc. are the current forms of mass entrepreneurship and innovation education in higher vocational colleges. There are still many problems in the construction of innovation and entrepreneurship curriculum system, which are mainly manifested in: lack of teaching content resources, lack of pertinence and systematicness; The curriculum is not perfect, most of them are skill teaching and relative case analysis, and there is a lack of comprehensiveness and planning; Traditional teaching methods, which are not well matched with the characteristics of the development of today's social times and the development characteristics of contemporary college students, and are less scientific and innovative; Innovation and entrepreneurship education is not closely integrated with professional education, and many courses are limited to "experiential" learning[3], lacking continuity and depth. The innovation and entrepreneurship curriculum lacks top-level design, and the imperfect curriculum system and content lead to inefficient and scattered innovation and entrepreneurship education in colleges and universities, and the quality of innovation and entrepreneurship talents training is uneven; The education of "curriculum ideological and political education" in the practice of innovation and entrepreneurship is not paid enough attention, the knowledge transfer and engineering case innovation, the concept of creating elements, optimizing thinking and transforming achievements in professional courses are insufficient, and the ethics of science and technology and engineering are lacking. The integration degree of professional knowledge is not strong, the technological process is unfamiliar, and the combination degree and general popularization of national norms and national standards are not high; The application of professional knowledge is not closely connected with the practice of mass entrepreneurship and innovation, the integration degree of each knowledge module is not high, the creativity is low, the scientific and technological level, technical content, technical and creative coverage of products are low, the effectiveness is weakened, the strength is not strong, and the sustainability and innovation are not enough, which leads to the insignificant effect of innovation and entrepreneurship education in colleges and universities.

\section{Research on Collaborative Education Countermeasures of Innovation and Entrepreneurship Education in Higher Vocational Colleges under the Background of "Curriculum Ideological and Political Education"}

\subsection{Construct the Ecological Training System of Innovation and Entrepreneurship Education in Higher Vocational Colleges}

With "curriculum ideological and political education" as the guiding ideology, Comply with the personnel training requirements of "thick foundation, emphasis on practice, hierarchy and innovation", and build an all-round ecological training system of dual-innovation education based on the multi-collaborative thinking of "management mechanism, operation mechanism, support system and practice platform", and create an educational practice platform of "cultural education-curriculum system-professional cultivation-project leading-dual-innovation actual combat"; Construct an educational path of collaborative education through innovation and entrepreneurship, Promote the flow of technical talents, knowledge and technology, Accelerate the integration and development of knowledge chain and practice chain, To train a group of innovative technical and technical talents facing the modern service industry, which integrates professional comprehensive ability, practical ability and innovation and entrepreneurship ability, the multi-level multiplication effect of innovation and entrepreneurship education is remarkable, and it has become the "support point" to incite the high-quality development of higher vocational colleges-the innovation and entrepreneurship education ecosystem of "5 platforms +2 chains" with everyone's brilliant effect. It has realized a three-dimensional innovation and entrepreneurship education system from "horizontal integration of specialization and innovation" to "vertical integration and penetration", that is, the whole chain innovation and entrepreneurship education practice path of "knowledge accumulation, skill practice and innovative application", which is conducive to promoting the cultivation of students' innovative spirit, entrepreneurial awareness and innovative and entrepreneurial ability (see Figure 1). 


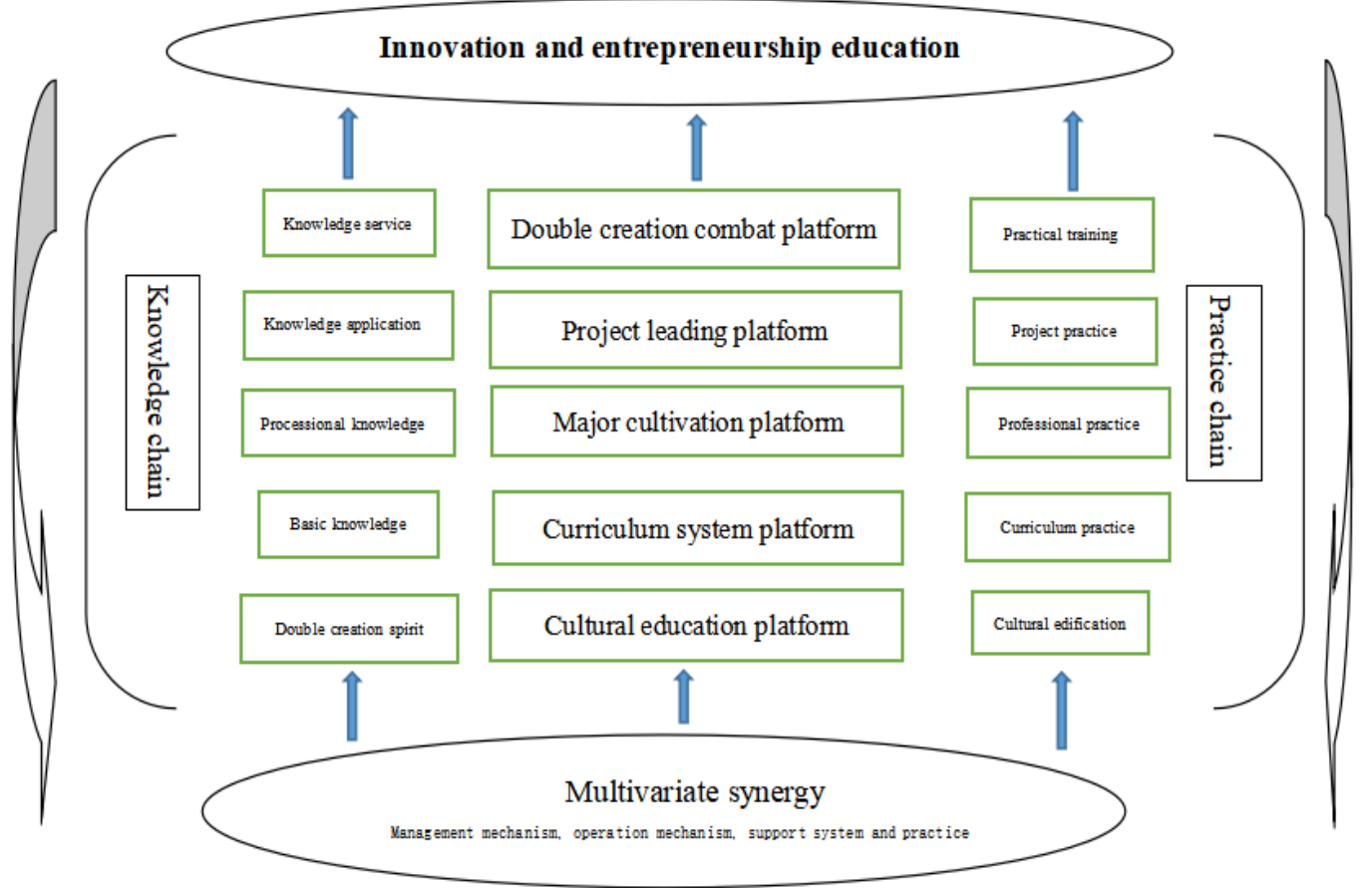

Figure 1: Ecological Training System of Innovation and Entrepreneurship Education in Technical Secondary Schools

\subsection{Construct the "Curriculum Ideological and Political" Education System of "Four in One" Innovation and Entrepreneurship Education}

Constructing the "curriculum ideological and political" education system in the process of innovation and entrepreneurship education in higher vocational colleges is conducive to strengthening the construction of teachers, enhancing the pertinence of students' innovation and entrepreneurship education, highlighting the ideological and political role of social practice, fully stimulating students' awareness of innovation and entrepreneurship, and expanding the "curriculum ideological and political" education in innovation and entrepreneurship practice activities. The Construction of "Curriculum Ideological and Political Education" in Double Creation Education Based on the "Challenge Cup" to Promote Education by Competition; The Construction of "Curriculum Ideological and Political Education" in Double Creation Education Based on the Construction of Entrepreneurship Practice Base; "Curriculum Ideological and Political Education" of Double Creation Education Based on League Learning Activities such as Social Practice in Cold and Summer; Finally, integrate a professional team of employment guidance, build a curriculum system of employment guidance, build a network platform of employment combination, and set up an employment association to enhance employability; "Integration" means to build a school-level employment counseling center, and the counseling and activities of the counseling center aim at cultivating students' awareness of career planning and improving their autonomous learning and employability. That is, the "curriculum ideological and political" education system of "four in one" innovation and entrepreneurship education. Under the concept and vision of "curriculum ideological and political education", schools, employers and families will assume the responsibility of guiding innovation and entrepreneurship, and students' first classroom[4] and second classroom will become the positions to cultivate students' innovation and entrepreneurship ability. Take students as the starting point, give full consideration to students' development needs, make overall plans and coordination, and form a joint force for innovation and entrepreneurship guidance. At the same time, the guidance of innovation and entrepreneurship should be carried out throughout the education work, and the coherence and phased development of the guidance of innovation and entrepreneurship should be strengthened. Only by strengthening all-round innovation and entrepreneurship guidance, forming a comprehensive and harmonious atmosphere and environment for innovation and entrepreneurship guidance, and making innovation and entrepreneurship guidance permeate all aspects of students' lives, can students' enthusiasm, autonomy and participation be strengthened, and the effectiveness of innovation and entrepreneurship work be effectively improved. Finally, the starting point is to help students improve their independent innovation and entrepreneurship, The working mode, which takes solving students' development needs at different stages as the breakthrough point, expanding students' coverage and benefits as the focus, and improving students' comprehensive quality and ability as the foothold, achieves the double improvement of overall innovation and entrepreneurship ability and innovation and entrepreneurship quality (see Figure 2).

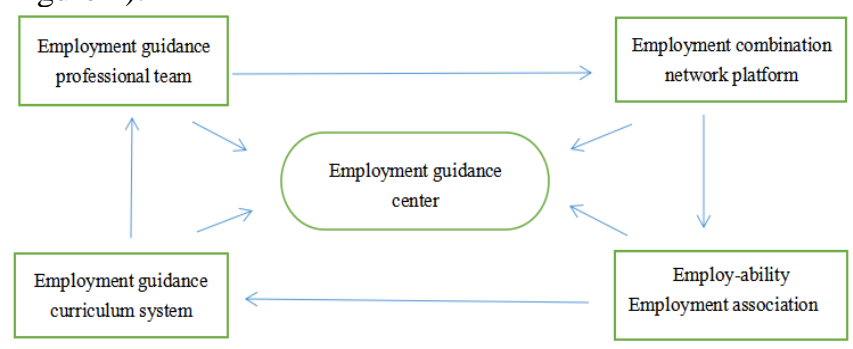

Figure 2: The "Curriculum Ideological and Political" Education System of "Four in One" Innovation and Entrepreneurship Education 
4.3 Construct A Collaborative Education System of Innovation and Entrepreneurship Education in Higher Vocational Colleges Based on the Background of "Curriculum Ideological and Political Education"

In the teaching of innovation and entrepreneurship related courses, Integrating the theoretical exploration, system construction and practical service of innovation and entrepreneurship guidance for higher vocational students, In the process of innovation and entrepreneurship guidance, we should take the concept of "curriculum ideological and political education" of educating all employees, the whole process and all-round education as the guiding principle[5], innovate and study in practice, and realize the promotion and development of innovation and entrepreneurship guidance for higher vocational college students. Enhance students' professional quality, cultivate students' scientific spirit, enhance students' ability to correctly understand, analyze and solve problems, improve the necessary quality of entrepreneurship, and tap the five dimensions of the connotation and extension of success literacy and the connotation of innovation, entrepreneurship and ideological and political education. Cultivate the applied thinking mode and establish the master spirit of serving the society and promoting the development of science and technology. At the same time, in the education and teaching work, we should establish an entrepreneurship education model specifically for college students to promote more college students to successfully start businesses, so as to achieve the promotion of entrepreneurial ability and the realization of personal value, and highlight the effectiveness of collaborative education (see Figure 3).

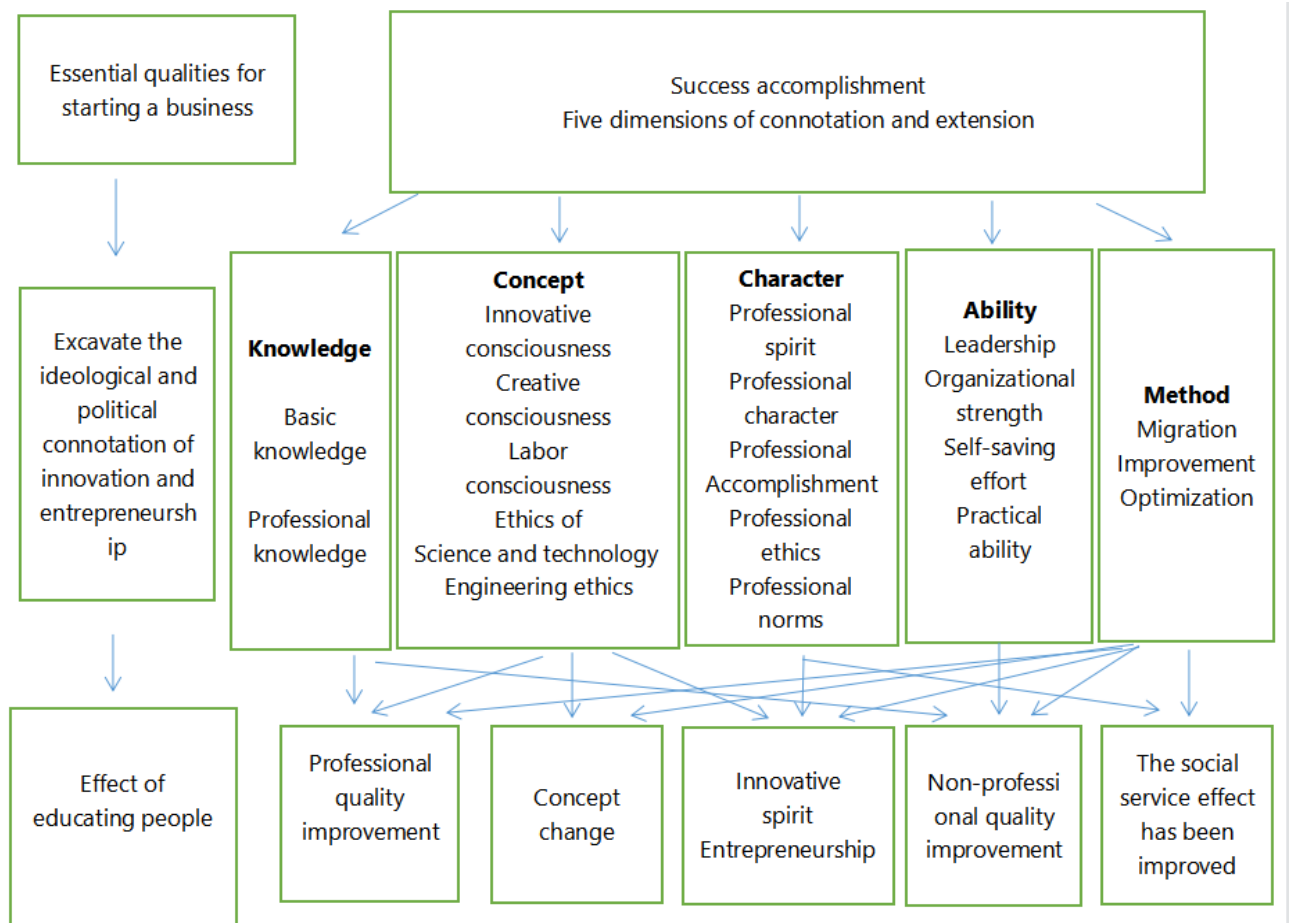

Figure3: Collaborative Education System of Innovation and Entrepreneurship Education in Higher Vocational Colleges Based on the Background of "Curriculum Ideological and Political Education"

\section{Conclusion}

To sum up, innovation and entrepreneurship education in higher vocational colleges is an important core content of innovative technical and technical personnel training and personal development in the new era. "Curriculum Ideological and Political Education" and innovation and entrepreneurship education in higher vocational colleges develop synergistically, Is conducive to promoting the reform and development of innovation and entrepreneurship education, In the good atmosphere of coordinated development of the two, Further strengthen the pertinence of teaching guidance for innovation and entrepreneurship education, From the perspective of "supply" and "supply and demand", we will continue to promote the reform of personnel training system, accelerate the formation of innovation and entrepreneurship education system from the perspective of "curriculum ideological and political education", realize the upgrading of personnel training, and provide sufficient guarantee for the development of society to train more outstanding technical and technical talents.

\section{References}

[1] Pang Lingxiao. Research on Classroom Integration of Innovation and Entrepreneurship Education and Ideological and Political Education [J]. Journal of Changchun University, 2019 (12): 103.

[2] Chu Yaping, Liu Gaofu. On the isomorphic symbiosis between mass enterpreneurship and innovation education and ideological and political education in colleges and universities [J]. Legal System and Society, 2020 (4): 181-182.

[3] Weng Weibin. From Following to Leading: The Turn of Innovation and Entrepreneurship Education in Higher Vocational Colleges under the Background of "Double High Plan" [J]. Education and Occupation, 2021 (10): 64-70.

[4] Wang Liguo. Research on Innovation and Entrepreneurship Education System in Higher 
Vocational Colleges from the Perspective of Educational Ecology Theory [J]. Vocational and Technical Education, 2020, 41 (5): 49-53.

[5] Wang Hailiang, Wang Xinxin. On the cultivation of college students' innovative and entrepreneurial spirit and the improvement of practical ability from the perspective of "curriculum ideological and political education" [J]. Journal of Social Sciences of Jiamusi University, 2020, 38 (6): 221-223.

\section{Author Profile}

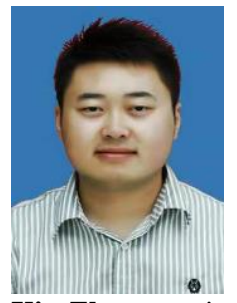

Xin Zhou received the bachelor degree in Chongqing Normal University, majored in Economics and Politics, from 2002 to 2005.He received the master degree in Southwest University of Political Science and Law, majored in Civil and Commercial Law, from 2008 to 2011.He now works in Chongqing College of Electronic Engineering, works as the Director of Human Resource Department. 